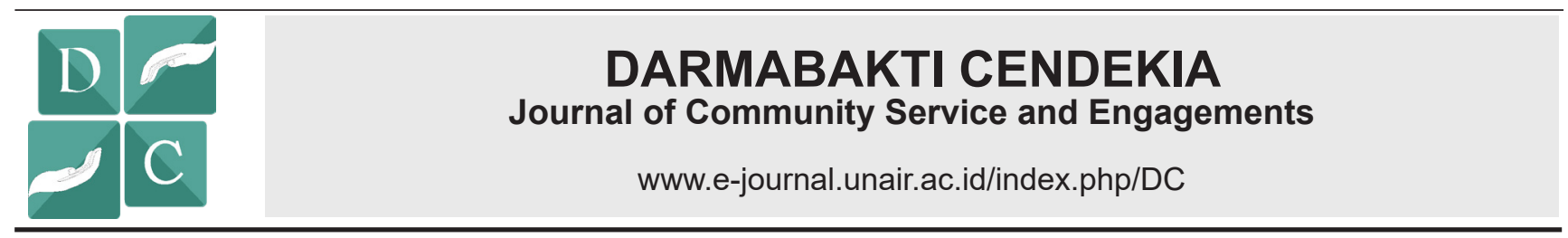

\title{
HEALTH EDUCATION OF MOTHER AND CHILD TO REDUCE PREVALENCE OF STUNTING IN MEDOKAN SEMAMPIR SURABAYA
}

\section{EDUKASI KESEHATAN IBU DAN ANAK UNTUK MENEKAN PREVALENSI BALITA STUNTING DI KELURAHAN MEDOKAN SEMAMPIR KOTA SURABAYA}

Scope:

Health

\section{Taufiqurrahman Sidqi ${ }^{* *}$, Eny Inayati ${ }^{2}$, Ario Imandiri ${ }^{3}$}

${ }^{1}$ Medical Laboratory Technology, Department of Health, Faculty of Vocational Studies, Universitas Airlangga, Surabaya-Indonesia
${ }^{2}$ Dental Technique, Department of Health, Faculty of Vocational Studies, Universitas Airlangga, Surabaya-Indonesia
${ }^{3}$ Traditional Medicine, Department of Health, Faculty of Vocational Studies, Universitas Airlangga, Surabaya-Indonesia

\section{A B S T R A C T}

\begin{abstract}
Background: Stunting is a chronic nutritional problem in infants characterized by a length or height that is lacking compared to age. The prevalence of stunting in Medokan Semampir Village was 30.48\% while the WHO standard states that free stunting if it is less than $20 \%$. Purpose: This activity aims to provide knowledge and skills to mothers who will and already have a toddler to prevent stunting in RW 02 Medokan Semampir. Method: This program was implemented in 4 steps those are planning, acting, observing, and evaluating. Result: The results of the health examination for toddlers who participated in the activity showed that there were no cases of stunting, but there were 3 toddlers who were underweight so it needed to be increasingly inadequate nutrition. Whereas the mother's examination showed 6 people who had low $\mathrm{Hb}$ levels and 2 people had high blood sugar levels. Toddler massage training provides the skills of mothers who had toddlers and toddler cadres in RW 02 to take independent action on their babies. Balanced nutrition counseling, exclusive breastfeeding, and mandatory immunization rose participant awareness in efforts to prevent stunting. Whereas the socialization of dental and oral health provided knowledge on how to clean the teeth of mothers and toddlers correctly and safely to avoid dental caries which can cause stunting in toddlers. Conclusion: This program was very useful for mothers and toddlers because it provides knowledge and skills in efforts to prevent the incidence of stunting toddlers.
\end{abstract}

\section{A B S T R A K}

Latar Belakang: Stunting merupakan permasalahan gizi kronis pada balita yang ditandai ukuran panjang atau tinggi badan yang yang kurang dibandingkan dengan umur. Prevalensi balita stunting di Kelurahan Medokan Semampir sebesar 30.48\% sedangkan standar WHO menyatakan bebas stunting apabila kurang dari 20\%. Tujuan: Kegiatan ini bertujuan memberikan pengetahuan dan ketrampilan kepada ibu-ibu yang akan dan telah memiliki balita mencegah stunting di lingkungan RW 02 Medokan Semampir. Metode: Kegiatan ini dilaksanakan dengan 4 langkah yaitu perencanaan, tindakan, observasi, dan evaluasi kegiatan. Hasil: Hasil pemeriksaan kesehatan balita yang ikut kegiatan menunjukkan tidak adanya kasus balita stunting namun ada 3 balita yang memiliki berat badan kurang sehingga perlu ditingkatkan asupan gizi cukup. Sedangkan pemeriksaan ibu menunjukkan 6 orang yang memiliki kadar $\mathrm{Hb}$ rendah dan 2 orang memiliki kadar gula darah tinggi. Pelatihan pijat balita memberikan keterampilan ibu-ibu yang memiliki anak balita serta kader balita RW 02 untuk melakukan tindakan mandiri kepada bayinya masing-masing. Penyuluhan gizi seimbang, ASI eksklusif, dan imunisasi wajib menumbuhkan kesadaran peserta dalam upaya pencegahan stunting. Sedangkan sosialisasi kesehatan gigi dan mulut memberikan pengetahuan cara membersihkan gigi ibu dan balita dengan benar dan aman untuk menghindari karies gigi yang dapat menyebabkan terjadinya stunting pada balita. Kesimpulan: Kegiatan ini sangat bermanfaat bagi ibu dan balita karena memberikan pengetahuan dan keterampilan dalam upaya mencegah kejadian balita stunting.
ART I C LE INFO

Recieved 30 September 2019 Accepted 24 October 2019 Online 20 December 2019

*Correspondence (Korespondensi): Taufiqurrahman Sidqi

E-mail:

taufiqurrahman-sidqi@vokasi. unair.ac.id

Keywords:

Stunting; Toddler; Mother and child; Health education

Kata kunci:

Stunting; Balita; Ibu dan anak; Edukasi kesehatan 


\section{PENDAHULUAN}

Stunting merupakan permasalahan gizi kronis pada balita yang ditandai ukuran panjang atau tinggi badan yang yang kurang dibandingkan dengan umur. Balita dikategorikan mengalami stunting apabila panjang atau tinggi badan lebih dari minus dua standar deviasi median standar pertumbuhan anak dari World Health Organization (WHO). Kondisi stunting tersebut dapat mempengaruhi kecerdasan anak karena pertumbuhan otak ikut terhambat. Selain itu, anak yang menderita stunting menjadi lebih rentan terhadap penyakit dan ketika dewasa beresiko mengidap penyakit degeneratif.

Berdasarkan data prevalensi balita stunting yang dikumpulkan WHO, Indonesia termasuk ke dalam negara ketiga dengan prevalensi tertinggi di regional Asia Tenggara. Rerata prevalensi balita stunting di Indonesia tahun 2005-2017 berdasarkan WHO sebesar 36,4\%. Hasil Riset Kesehatan Dasar (Riskesdas) dari tahun 2007-2013 menunjukkan prevalensi balita stunting di Indonesia cenderung statis. Pada tahun 2007, prevalensi balita stunting di Indonesia sebesar 36.8\% kemudian mengalami penurunan menjadi 35,6\% pada tahun 2010. Namun terjadi peningkatan kembali prevalensi balita stunting pada tahun 2013 menjadi 37,2\% (Pusat Data dan Informasi Kementerian Kesehatan RI, 2018). Sedangkan hasil Riskesdas tahun 2018 menunjukkan penurunan proporsi status gizi sangat pendek dan pendek menjadi 30,8\% (Depkes, 2018).

Prevalensi balita stunting di propinsi Jawa Timur pada tahun 2013 lebih rendah dari angka prevalensi nasional yaitu sebesar $35.8 \%$. Akan tetapi, angka tersebut mengalami sedikit kenaikan dibandingkan prevalensi stunting di Jawa Timur pada tahun 2007 sebesar 34.8\%. Prevalensi balita stunting pada tahun 2013 tersebut terdiri atas 16.8\% sangat pendek dan $19.0 \%$ pendek (Badan Penelitian dan Pengembangan Kesehatan Kemenkes RI, 2013).

Kelurahan Medokan Semampir merupakan salah satu kelurahan di wilayah Kecamatan Sukolilo, Kota Surabaya, Propinsi Jawa Timur. Kelurahan Medokan Semampir memiliki luas wilayah $1.87 \mathrm{~km} 2$ dengan jumlah RT sebanyak 60 dan RW sebanyak 9 (BPS, 2017). Berdasarkan hasil studi tahun 2017, prevalensi balita stunting di Kelurahan Medokan Semampir sebesar 30.48\%. Secara umum, hasil Pemantauan Status Gizi (PSG) pada tahun 2015, prevalensi balita stunting di Kota Surabaya sebesar 20.3\% sedangkan prevalensi stunting di propinsi Jawa Timur sebesar 27.1\% (Kementerian Kesehatan $\mathrm{RI}, 2016$ ). Berdasarkan standar yang diterapkan oleh WHO, suatu daerah dikategorikan tidak mengalami masalah gizi balita apabila prevalensi stunting pada wilayah tersebut kurang dari 20\% (Kementerian Kesehatan RI, 2016).

Selain faktor gizi buruk, sanitasi dan kebersihan lingkungan yang kurang memadai, pemberian ASI
Eksklusif pada balita, MPASI, dan imunisasi lengkap berperan penting pada kasus balita stunting di wilayah Kelurahan Medokan Semampir. Balita yang tidak mendapatkan ASI eksklusif beresiko 4,065 kali mengalami stunting sedangkan balita yang mendapatkan imunisasi tidak lengkap beresiko 3,743 kali mengalami stunting (Widyastuti, 2018). Oleh karena itu, diperlukan sosialisasi dalam bentuk penyuluhan kesehatan mengenai pentingnya imunisasi balita secara lengkap dan program mandiri Inisiasi Menyusu Dini.

\section{METODE}

Rangkaian kegiatan pengabdian masyarakat ini dimulai dari tahap perencanaan, tindakan, observasi, dan evaluasi. Tahap perencanaan disusun oleh tim pelaksana kegiatan dengan melibatkan mitra ketua PKK RW 02 Kelurahan Medokan Semampir. Kegiatan yang akan dilaksanakan disesuaikan dengan kondisi sasaran kegiatan yang diperoleh dari mitra kegiatan. Target dan sasaran kegiatan ini adalah ibu-ibu hamil, menyusui, dan yang memiliki anak balita. Oleh karena itu, tim pelaksana melakukan pengumpulan data ibu hamil, ibu menyusui, dan balita yang ada di lingkungan RW 02 Kelurahan Medokan semampir.

Tahap tindakan yang dilakukan meliputi pemeriksaan kesehatan ibu dan balita yang terdiri atas penimbangan, pengukuran badan balita, pengukuran lingkar kepala balita, pemeriksaan tekanan darah ibu, kadar hemoglobin ( $\mathrm{Hb}$ ) ibu, dan gula darah sewaktu ibu. Kegiatan kedua adalah pelatihan pijat balita untuk ibu-ibu yang memiliki balita dan kader balita di RW 02. Setelah pijat balita selesai, kegiatan dilanjutkan dengan penyuluhan dan sosialisasi mengenai balita stunting, cara pencegahannya, aspek penting kecukupan gizi seimbang, ASI eksklusif, serta imunisasi wajib. Kegiatan keempat diisi dengan penyuluhan mengenai kesehatan gigi dan mulut serta cara membersihkan gigi yang benar dan aman untuk ibu dan balita. Observasi dilakukan terhadap proses pelaksanaan kegiatan berdasarkan perencanaan dan tindakan yang telah disepakati oleh mitra dan tim pengusul kegiatan. Observasi dilakukan mulai dari pendataan sasaran kegiatan hingga selesainya kegiatan penyuluhan. Evaluasi dilakukan dengan pengisian kuesioner berupa pre test dan pos test sehingga dapat digunakan untuk analisis kendala, kelemahan, dan hambatan selama proses kegiatan berlangsung di lapangan.

Peralatan yang digunakan dalam kegiatan ini antara lain 1 set alat pemeriksaan kesehatan ibu; 1 set alat penimbang, pengukur badan dan lingkar kepala; boneka peraga; matras pijat; baby oil; handuk; LCD proyektor; laptop; layar proyektor; serta seperangkat sound system. 


\section{HASIL DAN PEMBAHASAN}

Kegiatan yang dilaksanakan dalam tahap persiapan antara lain survey lokasi kegiatan pengabdian masyarakat, koordinasi dengan mitra terkait target kegiatan, serta memberikan gambaran kegiatan pengabdian kepada masyarakat kepada mitra. Mitra kegiatan ini adalah ketua PKK RW 02 Kelurahan Medokan Semampir. Kelompok RW 02 memiliki total delapan kelompok RT. Data yang diperoleh dari Ketua PKK RW 02 terdapat 10 ibu hamil, 35 ibu menyusui, 5 orang kader balita, serta 5 orang kader kampung ASI.

Kegiatan pengabdian kepada masyarakat dilaksanakan pada tanggal 28 September 2019 di Balai RW 02 Kelurahan Medokan Semampir Surabaya. Tim pelaksana kegiatan terdiri atas gabungan 15 dosen, 1 tenaga kependidikan dan 8 perwakilan mahasiswa dari beberapa Program Studi di Departemen Kesehatan Fakultas Vokasi. Dosen, tendik dan mahasiswa yang berpartisipasi dalam kegiatan ini berasal dari Program Studi DIII Teknologi Laboratorium Medis, DIII Teknik Gigi, DIII Pengobat Tradisional, DIII Keselamatan dan Kesehatan Kerja (K3), DIII Paramedik Veteriner, dan DIV Teknologi Radiologi Pencitraan. Undangan yang hadir sebanyak 25 orang ibu, 21 balita, ketua PKK RW 02, ketua RW 02, 1 orang perwakilan Kelurahan Medokan Semampir, dan 2 orang pihak Puskesmas Keputih Surabaya.

Kegiatan pertama berupa pemeriksaan balita dan ibu hamil/ menyusui/ memiliki balita yang dikoordinir oleh dosen-dosen DIII Teknologi Laboratorium Medis (Gambar 1). Pemeriksaan pada balita meliputi pengukuran berat badan, panjang badan, serta lingkar kepala balita. Sedangkan parameter yang digunakan untuk pemeriksaan ibu adalah lingkar lengan, tekanan darah, $\mathrm{Hb}$, serta gula darah sewaktu.
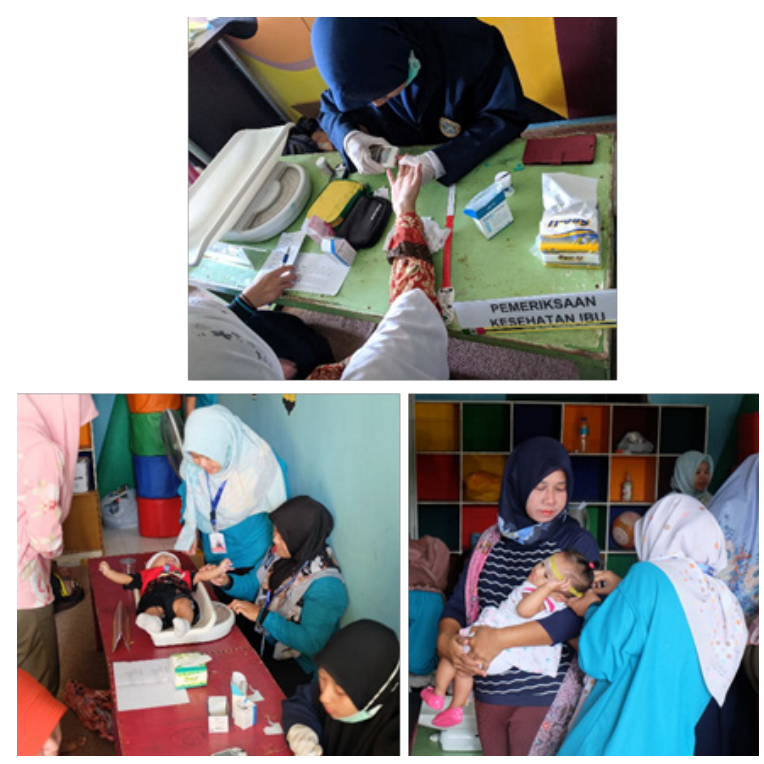

Gambar 1. Pemeriksaan ibu dan balita.
Parameter hasil pengukuran balita menggunakan nilai Z-score yang direkomendasikan oleh WHO. Dari hasil pemeriksaan 19 balita pada Tabel 1, 16 balita memiliki berat badan normal sedangkan 3 balita memiliki berat badan kurang. Seluruh balita memiliki panjang badan normal dan tidak ada yang memiliki tinggi badan pendek. Lingkar kepala semua balita dalam batas normal sesuai dengan pedoman Z-score WHO. Dari hasil pemeriksaan balita tersebut tidak ditemukan balita yang mengalami stunting, namun terdapat 3 balita yang memiliki berat badan kurang.

Tabel 1. Pemeriksaan kesehatan balita

\begin{tabular}{|c|c|c|c|c|c|c|}
\hline \multirow{2}{*}{$\begin{array}{l}\text { Usia } \\
\text { Balita } \\
\text { (bulan) }\end{array}$} & \multicolumn{2}{|c|}{ Berat Badan } & \multicolumn{2}{|c|}{ Panjang Badan } & \multicolumn{2}{|c|}{$\begin{array}{l}\text { Lingkar } \\
\text { Kepala }\end{array}$} \\
\hline & Normal & Kurus & Normal & Pendek & Normal & Kecil \\
\hline $0-12$ & 11 & - & 11 & - & 11 & - \\
\hline $12-24$ & 4 & 2 & 6 & - & 3 & - \\
\hline $24-60$ & 1 & 1 & 2 & - & 1 & - \\
\hline Total & 19 & & & 19 & 15 & \\
\hline
\end{tabular}

Pemeriksaan kesehatan ibu meliputi pemeriksaan tekanan darah, kadar hemoglobin (Hb), dan kadar gula darah sewaktu. Dari hasil pemeriksaan tekanan darah, semua ibu memiliki tekanan darah dalam batas normal serta tidak mengalami hipotensi maupun hipertensi. Akan tetapi, 6 orang memiliki kadar $\mathrm{Hb}$ rendah dan 2 orang memiliki gula darah di atas $200 \mathrm{mg} / \mathrm{dl}$ seperti pada Tabel 2. Asupan pangan yang mangandung zat besi diperlukan untuk ibu-ibu yang memiliki kadar $\mathrm{Hb}$ relatif rendah.

Tabel 2. Pemeriksaan kesehatan ibu

\begin{tabular}{|c|c|c|c|c|c|c|}
\hline Parameter & $\begin{array}{c}\text { Normal } \\
90 / 60- \\
139 / 89 \\
\mathrm{mmHg}\end{array}$ & $\begin{array}{l}\text { Rendah } \\
<90 / 60 \\
\mathrm{mmHg}\end{array}$ & $\begin{array}{c}\text { Normal } \\
12-16 \\
\mathrm{~g} / \mathrm{dL}\end{array}$ & $\begin{array}{c}\text { Rendah } \\
<12 \mathrm{~g} / \\
\mathrm{dL}\end{array}$ & $\begin{array}{c}\text { Nor- } \\
\text { mal } \\
\leq 200 \\
\mathrm{mg} / \mathrm{dl}\end{array}$ & $\begin{array}{c}\text { Tinggi } \\
\geq 200 \\
\mathrm{mg} / \\
\mathrm{L}\end{array}$ \\
\hline $\begin{array}{l}\text { Tekanan } \\
\text { Darah }\end{array}$ & 20 & - & & & & \\
\hline $\mathrm{Hb}$ & & & 14 & 6 & & \\
\hline $\begin{array}{l}\text { Gula } \\
\text { Darah } \\
\text { Sewaktu }\end{array}$ & & & & & 18 & 2 \\
\hline Total & & 20 & & 20 & & 20 \\
\hline
\end{tabular}

Pelatihan pijat balita pada sesi kedua dilakukan dengan penuh antusiasme dari ibu-ibu yang membawa anak balita karena dapat melakukan praktik langsung didampingi Ibu Myrna Adianti, M.Kes., Ph.D sebagai instruktur pijat yang merupakan dosen DIII Pengobat Tradisional dan 
dibantu 2 asisten. Metode yang dilakukan dengan visualisasi menggunakan LCD dan boneka peraga terlebih dahulu kemudian dilanjutkan dengan praktik langsung ke balita masing-masing (Gambar 1). Pemijatan pada balita diketahui dapat memicu peningkatan berat badan nenonatus (Daniati \& Novayelinda, 2011). Dengan adanya pelatihan pijat balita yang dilengkapi dengan tutorial dalam booklet yang dibagikan, ibu-ibu bisa menjaga tubuh balita masing-masing tetap segar serta dapat tumbuh dengan sehat.
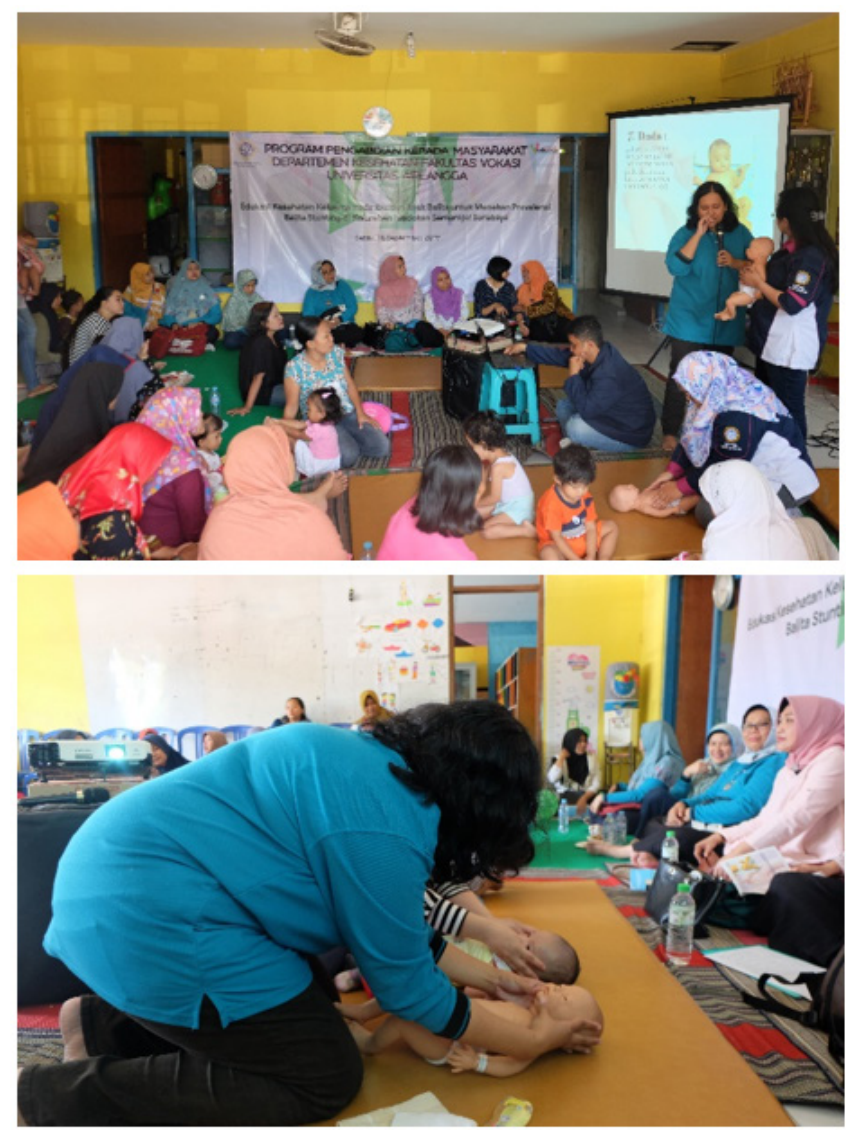

Gambar 2. Pelatihan pijat balita dengan pendampingan oleh instruktur pijat.

Sesi ketiga kegiatan pengabdian masyarakat diisi dengan penyuluhan mengenai balita stunting dan pencegahannya. Beberapa faktor kunci dalam mencegah terjadinya kasus balita stunting juga disosialisasikan seperti nilai penting kecukupan gizi seimbang, asupan ASI eksklusif, serta imunisasi wajib pada balita. Penyuluhan ini diisi oleh Ibu Ratih Damyanti, S.KM., M.Kes yang memiliki keahlian di bidang gizi serta salah satu aktivis ASI eksklusif sekaligus dosen DIII Keselamatan dan Kesehatan Kerja (Gambar 2). Upaya intervensi gizi spesifik untuk balita paling efektif dilakukan pada 1000 hari pertama kehidupan (HPK) dimulai saat ibu hamil, menyusui, dan anak usia 0-23 bulan. Periode 1000 HPK dimulai dari 270 hari selama kehamilan dan 730 hari pertama setelah bayi dilahirkan (Pusat Data dan Informasi Kemenkes RI, 2016). Oleh karena itu, ASI ekslusif dan kecukupan gizi terutama untuk ibu hamil dan menyusui sangat penting dalam pencegahan balita stunting.

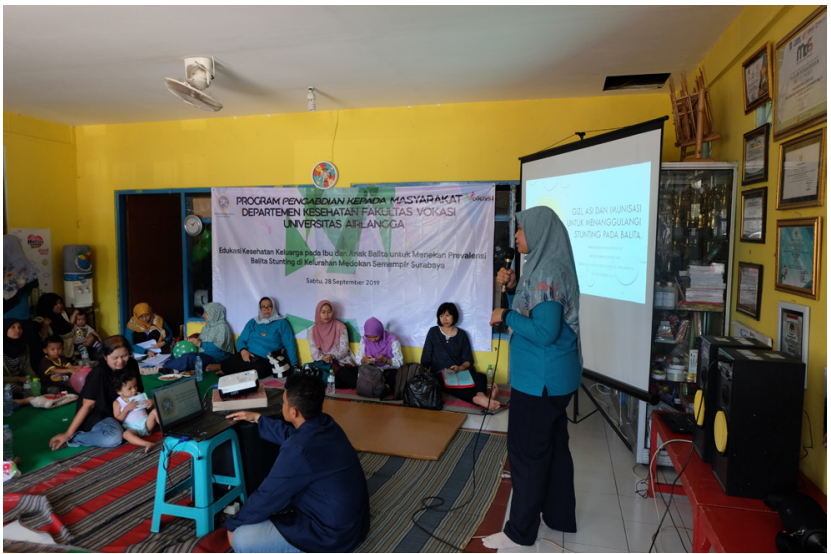

Gambar 3. Penyuluhan balita stunting danpencegahannya oleh Ibu Ratih Damayanti, S.KM., M.Kes.

Sosialisasi mengenai kesehatan gigi dan mulut untuk ibu dan balita dilakukan pada sesi keempat. Materi kesehatan gigi dan mulut ini diberikan oleh drg. Sri Redjeki Indiani, M.Kes sekaligus dosen DIII Teknik Gigi (Gambar 3). Faktor utama yang mempengaruhi kesehatan gigi dan mulut adalah terbentuknya karies gigi akibat cara membersihkan gigi dan mulut yang kurang tepat. Berdasarkan penelitian Rahman et. al (2016), terdapat hubungan tingkat karies gigi anak terhadap status gizi pendek (stunting). Indeks karies gigi pada kelompok anak gizi stunting lebih tinggi daripada kelompok anak gizi normal (Rahman et. al., 2016). Pada sesi ini, pemateri memberikan pengetahuan mengenai bahaya karies gigi, cara mencegah gigi berlubang, cara membersihkan gigi serta menggosok gigi dengan benar. Dengan adanya sosialisasi mengenai cara menjaga kebersihan gigi dan mulut balita dengan benar akan membantu ibu-ibu dalam memelihara kesehatan balita sehingga dapat menekan prevalensi balita stunting.

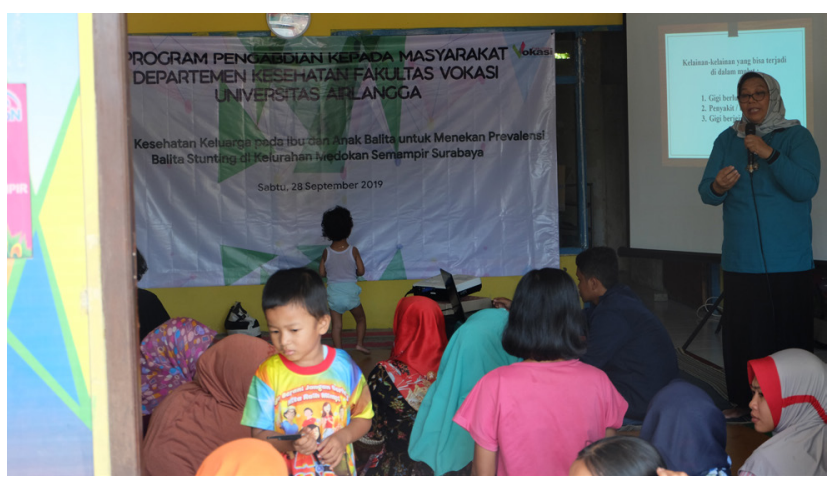

Gambar 4. Sosialisasi pemeliharaan kesehatan gigi dan mulut untuk mencegah prevalensi balita stunting.

Setiap peserta dan tamu undangan yang hadir diberikan booklet yang berisi tentang balita stunting 
dan pencegahannya serta materi yang disampaikan pada setiap sesi kegiatan (Gambar 4). Selain itu, dalam upaya kampanye mengurangi limbah plastik, tim pelaksana kegiatan juga membagikan botol minum (tumbler) dan kotak makanan kepada masing-masing peserta dan tamu undangan. Dengan adanya pola hidup yang bersih dan sehat maka dapat menekan prevalensi balita stunting di wilayah RW 02 Kelurahan Medokan Semampir Kota Surabaya.
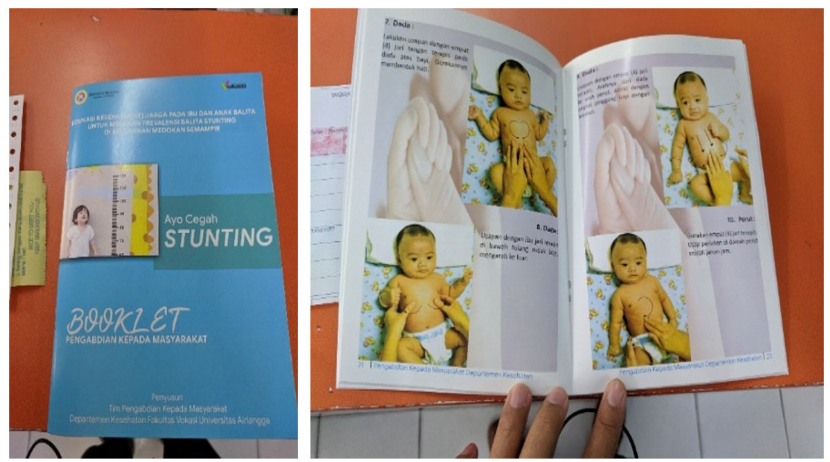

Gambar 5. Booklet pencegahan balita stunting yang disusun oleh tim pelaksana kegiatan pengabdian masyarakat Departemen Kesehatan Fakultas Vokasi.

Evaluasi yang dilakukan pada kegiatan ini berupa pengisian kuesioner yang dibagikan sebelum kegiatan dan setelah kegiatan untuk mengetahui dampak dari kegiatan yang dilaksanakan. Hasil dari kuesioner pre test menunjukkan rerata nilai sebesar 66,67 sedangkan setelah kegiatan selesai nilai post test menghasilkan rerata 78,57 dari range nilai $0-$ 100. Total 23 responden menunjukkan sebanyak 18 responden memberikan ASI eklusif pada bayinya dan 5 responden tidak memberikan ASI ekslusif. Dengan adanya sosialisasi ini diharapakan ibuibu akan sangat memperhatikan pemberian ASI eksklusif terhadap bayinya masing-masing.

\section{KESIMPULAN DAN SARAN}

Kegiatan pengabdian kepada masyarakat ini sangat bermanfaat bagi ibu dan balita. Kegiatan ini dapatmeningkatkanpengetahuan danketerampilan dalam upaya mencegah prevalensi balita stunting yang ditunjukkan dengan peningkatan nilai pre test dan pos test dari 66,67 menjadi 78,57. Hasil pemeriksaan kesehatan balita yang datang dalam kegiatan menunjukkan tidak adanya kasus balita yang mengalami stunting. Akan tetapi, perlu adanya penyebaran info dan pemantauan oleh kader balita dan kelompok PKK bagi warga yang tidak hadir dalam kegiatan pengabdian kepada masyarakat ini. tim dosen pelaksana Departemen Kesehatan atas kerjasama dan bantuannya serta kepada Fakultas Vokasi Universitas Airlangga atas dana RKAT sehingga kegiatan ini dapat terlaksana. Penulis menyatakan tidak ada konflik kepentingan dengan pihak-pihak yang terkait dalam kegiatan pengabdian kepada masyarakat di RW 02 Kelurahan Medokan Semampir Kota Surabaya.

\section{DAFTAR PUSTAKA}

Badan Penelitian dan Pengembangan Kesehatan Kementerian Kesehatan RI. 2013. Pokok-Pokok Hasil Riset Kesehatan Dasar 2013 Propinsi Jawa Timur. Jakarta: Kemenkes RI.

BPS. 2017. Luas wilayah Kota Surabaya menurut Kelurahan tahun 2016. Available from: https://surabayakota.bps.go.id/ statictable/2018/01/30/581/luas-wilayah-kotasurabaya-menurut-kelurahan-2016-.html. Diakses: 2 Februari 2019.

Daniati, M., Novayelinda, R. 2011. Pengaruh pijat bayi terhadap peningkatan berat badan neonatus. Jurnal Ners Indonesia Vol. 2(1). Pp 11-20.

Departemen Kesehatan. 2018. Potret Sehat Indonesia dari Riskesdas 2018. Available from: http://www.depkes.go.id/article/ view/18110200003/potret-sehat-indonesia-daririskesdas-2018.html. Diakses: 28 Januari 2019.

Kementerian Kesehatan RI. 2016. Buku Saku Pemantauan Status Gizi dan Indikator Kinerja Gizi Tahun 2015. Jakarta: Badan Penelitian dan Pengembangan Kesehatan Kementerian Kesehatan.

Kementerian Kesehatan RI. 2016. Situasi Balita Pendek. Jakarta: Kementerian Kesehatan RI.

Pusat Data dan Informasi Kementerian Kesehatan RI. 2018. Situasi Balita Pendek (Stunting) di Indonesia; dalam Buletin Jendela Data dan Informasi Kesehatan. Jakarta: Kementerian Kesehatan RI.

Rahman, T., Adhani, R., Triawanti. 2016. Hubungan antara status gizi pendek (stunting) dengan tingkat karies gigi. Dentino Jurnal Kedokteran Gigi Vol. 1(1). Pp 88-93.

Widyastuti, V. 2018. Faktor-faktor yang mempengaruhi kejadian stunting pada balita di Kelurahan Medokan Semampir Surabaya. Skripsi. Surabaya: Universitas Airlangga.

\section{UCAPAN TERIMA KASIH}

Penulis mengucapkan terima kasih kepada 